\title{
4 The impact of COVID-19 on the Austrian federal system
}

\author{
Peter Bußjäger and Mathias Eller
}

\subsection{Introduction}

Like other countries, Austria has been hit hard by COVID-19. However, the mortality rate has remained rather low in comparison to other nations. The pandemic strikingly shows not only the vulnerability of society to an invisible exigent adversary which threatens people's physical health but also the difficulties an emergency of this scope poses for legislative and executive bodies. Concerning federalism, at first glance, the impact of the pandemic has been limited so far. For example, until September 2020, there have been no modifications to the Federal Constitution concerning the distribution of competences in legislation or execution. Nevertheless, it is important to investigate the extent to which the federal system in Austria was affected by the virus and how the different levels of government coped with this state of emergency.

Therefore, this chapter is structured as follows: First, the current situation of COVID-19 in Austria is examined, including an assessment of the health and economic costs incurred (2). Second, the distribution of competences on health matters between the Federation and the Länder (States) is outlined. The subsequent analysis focuses on the legislative and administrative activities on the federal and Land level as well as intergovernmental relations in this context (3). The final section concentrates on the transformations in the practice of federalism in Austria due to the crisis (4).

Numerous governance phenomena occurred in Austria during the crisis. They can be summarized as follows:

1 It is a well-known fact that, in times of crisis, there is a tendency to call for comprehensive and uniform solutions. This has also been the case in Austria;

2 States of emergency trigger the elevation of executive over legislative bodies;

3 Länder regulations deviated from Federal Government measures enacted for the whole of Austria due to the differentiated effects of the pandemic in different areas;

4 The Austrian type of cooperative federalism seems to be an effective way to cope with the pandemic;

5 The distribution of competences on health matters between the Federation and the Länder has so far not been an obstacle to the sufficient supply of health services.

All in all, it seems that Austria overcame the "first wave" of the pandemic well (Table 4.1). This has surprised various experts who feared the negative effects of the

DOI: $10.4324 / 9781003251217-4$ 
Table 4.1 Key Statistics on COVID-19 in Austria as of 10 January 2021

\begin{tabular}{lllll}
\hline $\begin{array}{l}\text { Cumulative } \\
\text { Cases }\end{array}$ & $\begin{array}{l}\text { Cumulative Cases per } \\
\text { 100,000 Population }\end{array}$ & $\begin{array}{l}\text { Cumulative } \\
\text { Deaths }\end{array}$ & $\begin{array}{l}\text { Cumulative Deaths per } \\
\text { 100,000 Population }\end{array}$ & $\begin{array}{l}\text { Case Fatality } \\
\text { Percentage }\end{array}$ \\
\hline 378,110 & $4,198.2$ & 6,614 & 73.4 & 1.7 \\
\hline
\end{tabular}

Source: World Health Organization Weekly epidemiological update - 12 January 2021. Geneva: WHO, 2021. Available from https://www.who.int/publications/m/item/weekly-epidemiological-update

opaque and complicated distribution of competences, especially in the hospital sector. In an analysis published on the Cambridge Core blog on 12 April 2020, author Thomas Czypionka wrote:

Despite its fragmented healthcare system, strong federalism, and relatively poor public health capacity, Austria has so far fared surprisingly well in the current crisis. After the swift and decisive introduction of rather drastic measures, infections have shown a considerable decline. As one of the first European countries to impose them, restrictions will be gradually lifted in the coming weeks.

The Austrian form of cooperative federalism has been nevertheless challenged by this new threat and has, so far, passed the test. However, it appears that mistakes have been made in addressing the outbreak, and in the most recent developments, considerable communication problems have arisen between the Federal Government and the Länder. In order to keep the spread of the virus and its impact on the health and economic system in Austria under control, smart Federal Government coordination with responsive and creative Land and local governments attuned to their situations will be required in the coming months. The prevalence of the executive bodies on the other hand - especially the Federal Government - fosters to some degree the development of features that normally occur in decentralized unitary states.

\subsection{COVID-19 in Austria}

The COVID-19 pandemic hit Austria at the end of February 2020, as the new Federal Government formed in January 2020 was only a few weeks into its term. It emerged as a completely unexpected challenge for the coalition of the conservative Peoples' Party and the Greens who had never been in a coalition at federal level before.

As noted above, Austria managed the initial phase of the pandemic comparatively well. After the first wave began at the end of February with the first confirmed infections detected in Innsbruck, it peaked at the end of March with more than a 1,000 infections per day. The lowest level of infections was reached in the middle of June, as the daily infection rate ranged between 20 and 50 new confirmed infections per day.

At the beginning of September 2020, Austria had approximately 28,000 persons in total infected with the virus, with approximately 24,000 recovered, 3,300 active cases, and 726 deaths from COVID-19. At this point in time, the death rate per 100,000 inhabitants in Austria was 8.30 (compared with 0.64 in South Korea; 11.24 in Germany; 5.59 in France; 6.35 in Sweden; 6.76 in the USA; and 62.49 in the UK (Neuwirth 2020)). 


\section{Peter Bußjäger and Mathias Eller}

As the restrictions imposed on the general public to control the spread of the virus were lifted (such as the restrictions on free movement at the end of May and the re-opening of national borders in June), the infection rate began to increase again. At the beginning of September 2020, Austria faced between 300 and 400 new infections per day. The Federal Government took action to ensure that Austria does not reach the point of exponential growth in cases. Statistics also show that the situation in the hospitals remains stable and does not mirror the growth of infections.

Despite the fairly good performance in controlling infection rates during the first wave of the pandemic, the Austrian economy was hit heavily by the virus control measures. Gross national product sank by about 8 percent. Unemployment increased by leaps and bounds, as did "short-time working," ${ }^{1}$ which is an attempt to encourage companies to retain their employees rather than lay them off. The budgets of the Federation as well as those of the Länder and municipalities are out of balance. On the one hand, tax revenues are falling considerably, while on the other hand, expenditures are increasing to mitigate the economic impact of the crisis.

On 4 September 2020, the Federal Government initiated its four-phase "traffic light system" of COVID-19 control measures. The system operates a color-coded scale of the severity of the situation in a given area. "Green" denotes that minimal precautions are required, while "red" indicates that the most stringent controls should be implemented. "Orange" and "yellow" are gradations between the two ends of the spectrum. The system initially assigned "yellow" status to the capital Vienna and the next largest cities in Austria (Graz and Linz) as well as to a district in Tyrol. The rest of Austria was given a "green" status.

A commission provides advice and recommendations to the Federal Minister for Health. Based on its recommendations, the Minister can give instructions to the Land Governors who are required to either implement the directives by decrees for the Land concerned or instruct the district authorities to implement such measures in their respective territory. The commission is composed of representatives of the Federal Ministry for Health, experts from the Agency for Health and Food Security, medical experts from universities, and representatives of the Länder carries out the risk assessment and determines the traffic light of the respective districts. This composition is an example of the functioning of cooperative federalism in Austria.

The "traffic light system" is a challenge for the Austrian federal system as the Land Governors have to execute directives of the Federal Minister for Health as well as the recommendations of the commission. It is imperative to note that the Land and the federal level may have different interests. In addition, the Land Governors are faced with the problem that the legal basis of binding decrees on various matters is weak. The Constitutional Court (14 July 2020, V 363/2020) ruled parts of the decree of the Federal Minister for Health (which regulated the "Lockdown" in March and imposed extensive restrictions of free movement in Austria) to be an infringement of law. As a result of this judgement, the Federal Parliament as the competent legislator modified the existing law in order to make restrictions as they are foreseen in cases of "red" or "orange" compatible with the constitution. At the initiation of the traffic light system in September 2020, this law had not even been discussed in parliament, and it will not enter into force before October 2020. 


\subsection{COVID-19 and federalism in Austria}

\subsubsection{Distribution of competences in health matters}

According to the Austrian Federal Constitution (B-VG), competences on health matters are distributed between the Federation and the Länder (States). However, the Federation has the competence to pass and execute laws concerning public health, except for those concerning the organization of hospitals and municipal sanitation (Art. 10 para $1 \mathrm{n} .12 \mathrm{~B}-\mathrm{VG})$. This includes the competence to manage the prevention of epidemics and pandemics. Art. 12 para $1 \mathrm{n}$. 1, B-VG stipulates that the organization of hospitals is the business of the Federation in regards to the basic legislation, while legislation on implementation and enforcement is the business of the Länder. Public hospitals are managed in most cases by Länder or municipalities and financed by a very complicated system of social insurance and financial equalization.

According to Art. 10 para 1 n. 12 B-VG, federal administration of public health has to be executed by the Land Governors and the subordinated district authorities of the Länder (so-called indirect federal administration). According to Art. 103 para 1. B-VG, Governors are bound to the instructions of the Federal Government and individual Federal Ministers (Art. 20). In the case of the pandemic, they are bound to those of the Federal Minister for Health from the Green Party. In order to effect the implementation of such instructions, they are also obliged to employ the powers available to them in their capacity as a functionary of the province's autonomous sphere of competence.

This system of indirect federal administration is characteristic of Austrian federalism and its cooperative element: on the one hand, the Federal Government is legally in a position to enforce its will vis-à-vis the Land governors; but on the other hand, the action taken also depends on the capacities of the Länder and their commitment to confronting the crisis.

\subsubsection{Measures implemented by the authorities on the federal and land level to prevent further spread of the pandemic}

Based on the aforementioned provisions, the competent authorities execute the federal Epidemics Act 1950 ("Epidemiegesetz"), which has roots stretching back to 1913. As this law was ill-suited to deal with the current epidemic, various new regulations were passed by the Austrian parliament in the early stages of the pandemic. The most notable of these is the "COVID-19-Maßnahmengesetz" ("COVID-19 Action Law"), which came into force on 16 March 2020. At this stage, the second chamber, the Austrian "Bundesrat," agreed unanimously to all legislative measures proposed by the first chamber. In some fields, such as public procurement law, COVID-19 legislation even led to a temporary loss of state competences.

As a result, the competent authorities on the federal and Land level are now entitled to issue decrees prohibiting entry to business premises (for customers, $\S 1$ ) as well as other specified locations ( $§ 2$ ). Decrees can be issued by the Minister of Health (no. 1), the Governor of the Land (no. 2), and the district administrative authority (no. 3) in their respective jurisdictions (the entire country, the Land, the district territory which is an administrative subunit of the respective Land or parts of the district territory). 
Based on the COVID-19-Maßnahmengesetz, the enforcement bodies have issued various ordinances that executed the "lockdown" in Austria by prohibiting the "entering of public places." Exceptions have been made for activities required to meet basic daily needs (such as food shopping). The Minister of Health also issued an ordinance on provisional measures to prevent the proliferation of COVID-19, prohibiting access to the customer areas of retail and service premises and of leisure and sports facilities.

On the regional level, Tyrol - the Land that had initially been affected by the crisis more than any other - enacted stricter lockdown regulations than those implemented by the Federal Government across the entire Austrian territory. Although the ability of the Länder to take independent action ultimately is always dependent on the goodwill of the Federal Government, the Tyrolean approach illustrated a certain degree of flexibility in the management of the crisis. This approach provides the Länder with the ability to implement a differentiated COVID-19 response according to local and regional conditions. However, the ordinance that had provided for an even stricter lockdown in the Land Tyrol was also recently found to be unlawful by the Constitutional Court (10 December 2020, V 512/2020). In the light of the ruling issued in the summer, this decision was not surprising at all.

The fact that all the legal instruments used to take action during the crisis have already been amended several times reflects the pressure under which the legislative and regulatory bodies have been working as well as the need to continually adapt the legal framework to the dynamic developments.

\subsubsection{Intergovernmental relations and cooperative federalism}

Intergovernmental relations and the Austrian form of cooperative federalism are closely connected and interdependent. The better the communication and coordination between the different levels of government, the more effective cooperative federalism is. Overall, it can be said that cooperation between the Federation, the Länder, and the municipalities proceeded relatively smoothly during the zenith of the "first wave." Not surprisingly, all levels of government emphasized the good cooperation that has been maintained so far during the outbreak. Since the beginning of the crisis, tensions and differences in approach have only emerged in isolated cases. In Vienna, for example, the city opened its parks to the public, while those owned by the Federal Government remained closed.

Perhaps, more prominently, critics have expressed in numerous domestic and foreign media outlets that the authorities of the province of Tyrol reacted inadequately and too slowly to the spread of the virus in the Tyrolean ski resort of Ischgl. The time has not yet come to assign fault for mistakes that might have been made in the response to the outbreak. Since the executing authorities are acting under the responsibility of the Federal Government, their performance should also be examined in due course. To this point, the good cooperation between the Federal Government and Land authorities in tackling the crisis does not seem to have been adversely affected by these criticisms.

As the number of Coronavirus infections increased in early September, tensions between the competent authorities became heightened. The Länder demanded clearer guidelines in handling the crisis and pointed out that the regional administrative 
authorities are understaffed. In reaction, additional military personnel were requested by Land governments such as Tyrol in order to support the local health authorities and to ensure that the current COVID-19 regulations at the state borders can be executed properly. This example demonstrates the importance of coordination and cooperation between all levels of government as well as a recognition that the competent authorities work under tremendous pressure in emergency situations such as the COVID-19 crisis.

Although the new "traffic light system," introduced at the beginning of September can be seen as a typical example of Austrian cooperative federalism (composed of representatives of federal ministries, Länder and experts), its implementation caused various problems. This was due to the lack of transparency in the decision-making process and the unclear legal basis upon which Land Governors and district authorities were required to base their regulations. It must be regarded as a failure of the Federal Government that it was not able to elaborate the necessary laws required for the system and present them to parliament in a timely manner.

\subsubsection{The role of land governments}

Despite the far-reaching powers of the Federal Government, it remains the task of the Länder to provide sufficient capacity in hospitals and in relation to testing, for example. To date, this division of responsibility has worked well, especially if you compare Austria to other countries dealing with the crisis. However, as outlined before, as the "second wave" of the pandemic has begun to emerge in Austria, capacity constraints, especially in terms of auxiliary personnel, appear to be becoming increasingly problematic and are engendering tensions between the federal and Land authorities.

The pandemic clearly shows the limits of indirect federal administration. The Federation and Länder depend on each other: while the Federation has the exclusive competences for legislation, it depends on the Land authorities and their willingness and commitment to implement federal regulations.

However, the key role in indirect federal administration is played by the Land Governor and not the whole of the Land government. The Governor receives the instructions of the Federal Government and passes them to the administrative authorities in their respective jurisdiction. Thus, the role of the Land Governments in handling the crisis is limited, despite the fact that it is clear that the respective members of these governments, competent for matters of health or security, play an important role in a crisis such as the COVID-19 pandemic.

\subsubsection{The role of local governments}

The lowest territorial level in Austria was severely affected by the COVID-19 crisis, particularly with regards to finances. Experts estimate that municipalities will lose up to 2 billion euros as a result of decreased incomes and increased expenditures. The aid packages provided by the Federal Government are currently far from sufficient to overcome the deficits incurred to date.

Although municipalities do not participate directly in the distribution of competences in Austria, Art. 118 para 1 B-VG states that "a municipality has its own sphere 
of competence and one assigned to it either by the federation or the province." The "own sphere of competence" comprises all matters exclusively or preponderantly the concern of the local community as embodied by the municipality, and suited to performance by the community within its local boundaries. Legislation shall expressly specify matters of that kind as being such which fall within the municipality's own sphere of competence (para 2).

Furthermore, a municipality is guaranteed official responsibility in its own sphere of competence for performance of specific enumerated matters such as local public security administration, the regulation of local public events or local sanitary administration (örtliche Gesundheitspolizei), particularly in the field of emergency and first aid services as well as matters pertaining to deaths and interment.

In fact, there was no area of municipal responsibility that remained unaffected by the crisis. The closure of schools, kindergartens, and after-school care centers required a very rapid response and support had to be provided for parents in system-critical professions. In the same vein, important municipal services and facilities had to be closed as well. This not only applied to the cultural and sports sectors but also to waste material collection centers and many municipal offices. Shopping services were organized for the elderly to ensure that vulnerable population groups were protected as best as possible. In addition, the statutory cities ${ }^{2}$ were particularly hard hit by the crisis because, unlike ordinary local municipalities, they also had to cope with the tasks of indirect federal administration.

To date, municipalities have been a key player in managing the crisis, and they will remain a crucial partner in keeping the pandemic under control in Austria in the future. It is for precisely this reason that they should be provided with sufficient financial resources to perform the functions necessary in the COVID-19 context.

\subsubsection{Measures within the framework of private-sector administration}

Both the Federal and Land governments are currently attempting to mitigate the economic consequences of the crisis through various financial support measures. If they do so within the framework of private-sector administration, they are not bound by the otherwise applicable division of competences (Art. 10 to $15 \mathrm{~B}-\mathrm{VG}$ ) in line with Art. 17 B-VG. The measures range from aid for "short-time working" to hardship funds and fixed cost subsidies for affected companies.

There is no doubt that the measures taken will have serious budgetary consequences for the federal, Land, and local governments. It will therefore be interesting to see how the accumulated debts are distributed among the authorities. According to the latest reports, the next fiscal equalization negotiations, which have the potential to be explosive, will be postponed due to the exceptional situation. Although the extent of the economic consequences of the COVID-19 crisis cannot yet be assessed, there is no question that they are far-reaching.

\subsection{Case study of innovation/transformations in COVID-19 and federalism in Austria}

Due to its competences regarding legislation and execution of governance functions according to Art. 10 para 1 n. 12 (health care), the Federation was able to impose severe restrictions on daily life in Austria during the first wave of the pandemic. 
The authorities of the Länder had to execute these provisions under the directive of the Federal Minister for Health. This transferred additional de facto power to the Federal Government, even though all proceedings were constitutionally valid. Therefore, during this period, Austria somewhat transitioned from a federal into a decentralized unitary state. The role of the Federation in agenda setting was strengthened. Vertical coordination appears to have to be much more relevant than horizontal cooperation.

On the other hand, new forms of cooperative federalism were introduced or intensified. Video conferences between the staff of the Federal Ministries and the Land administrations were held on a daily basis, often with the participation of political representatives.

While the COVID-19 crisis strengthened centralized legislation and emphasized the vertical aspects of Austrian federalism, it also made visible the important role of the Land authorities in executing the virus control regulations. Specifically, the district authorities ("Bezirkshauptmannschaften"), which were established as institutions of monarchical administration in 1868 and transferred to the Länder in 1920, are functioning as health authorities.

The COVID-19 crisis also seems to have advanced the process of the digitization of Austrian administrative governance. Not only have video conferences become commonplace, but digitization of administrative and judicial procedures has also taken place. It can be anticipated that this will have an enormous impact on the way in which governments will communicate with their citizens in the future.

The impacts of this development of Austrian federalism are not yet clear. In administrative theory, federalism is often seen as an obstacle to efficient E-Government. The COVID-19 crisis might encourage the establishment of new E-Government platforms including services provided by the Federation as well as by the Länder and municipalities. This example indicates the growing importance of cooperative federalism in Austria.

Finally, it can be said that the COVID-19 crisis marginalized the role of the federal parliament as well as Land parliaments. The National Council and the second chamber of the Austrian parliament, the Federal Council, as well as the Landtage (Austria's Land parliaments) could only deliver legal empowerment of the Governments. Based on this legal provisions, the governments decreed various incisive restrictions of public life.

\section{Notes}

1 Short-time working or short time is a governmental unemployment insurance system in which private-sector employees agree to or are forced to accept a reduction in working time and pay, with the state making up for all or part of the lost wages.

2 A statutory city is vested, in addition to its purview as a municipality, with the powers and duties of a district administrative authority.

\section{Bibliography}

Austrian Federal Constitution, 1945. Austria. Available from: https://www.ris.bka.gv.at/ GeltendeFassung.wxe?Abfrage=Bundesnormen\&Gesetzesnummer $=10000138$ [Accessed 23 March 2021].Constitutional Court, 2020. V 363/2020. Austria, July 14. Available from: https://www.vfgh.gv.at/downloads/VfGH-Entscheidung_V_363_2020_vom_14._Juli_ 2020.pdf [Accessed 23 March 2021]. 


\section{Peter Buß̈̈̈ger and Mathias Eller}

Constitutional Court, 2020. V 512/2020. Austria, December 10. Available from: https://www. vfgh.gv.at/downloads/VfGH_10.12.2020_V_512_2020_Tirol_Verlassen_des_Wohnsitzes. pdf [Accessed 23 March 2021].

Czypionka, T., 2020. Austria's Response to the Coronavirus Pandemic - A Second Perspective. Cambridge Core blog, 12 April. Available from: https://www.cambridge.org/core/ blog/2020/04/12/austrias-response-to-the-coronavirus-pandemic-a-second-perspective/ [Accessed 23 March 2021]. Government of Austria, 2020a. Corona Ampel (COVID-19 Traffic-Light-System). Vienna, 4 September. Available from: https://corona-ampel.gv.at/ [Accessed 23 March 2021].

Government of Austria, 2020b. COVID-19-Maßnahmengesetz - COVID-19-MG (StF: BGBl. I Nr. 12/2020 (NR: GP XXVII IA 396/A AB 102 S. 16. BR: AB 10287 S. 903.). Vienna, 16 March. Available from: https://www.ris.bka.gv.at/GeltendeFassung.wxe? Abfrage $=$ Bundesnormen $\&$ Gesetzesnummer $=20011073$ [Accessed 23 March 2021].

Neuwirth, E., 2020. Erich Neuwirths COVID-19-Analysen. Available from: https://just-thecovid-facts.neuwirth.priv.at/ [Accessed 23 March 2021]. 